\title{
Ownership, Risk and Efficiency in the Banking Sector of the ASEAN Countries
}

\author{
http://doi.org/10.21272/fmir.3(2).5-16.2019
}

Khurshid Djalilov
Bournemouth University, UK

Trang Ngoc Lam

Bournemouth University, UK

\begin{abstract}
Research investigating the determinants of banking performance has been at the centre of policy and academic debate following the global financial crisis (2007-2009). Thus, the purpose of this paper is to contribute to the assessment of the factors impacting banking efficiency. Whilst there are many studies investigating this problem in developed and emerging countries, there is little research addressing this question in the countries of the Association of South East Asian Nations (ASEAN). The ASEAN as a region is among one of the fastest growing in the world. Using system GMM this paper examines the effects of ownership and risk on efficiency for 71 banks of the ASEAN countries, considering the period 2011-2016. All financial and economic data are deflated by their corresponding Consumer Price Indices (CPIs) to the 2011 price level to control for inflation effects and are converted to constant US dollars by using the 2005 PPP conversion rates. We use stochastic frontier analysis (SFA) to estimate a measure of bank efficiency. This allows the measurement of inefficiency for each bank from the best-practice frontier incorporating bank, industry- and country-specific variables. Moreover, this study explores the efficiency effects of six categories of bank ownership such as widely-held, bank, institutional, industry, family and state. The findings indicate that different categories of ownership have different effects on bank efficiency. Particularly, they show that the widely-held banks and the banks with the bank controlling ownership experience lower efficiency. The results additionally indicate that overall risktaking improves efficiency; however, higher levels of risk-taking lower efficiency. The paper also provides some relevant policy-implications.
\end{abstract}

Keywords: ASEAN countries, Bank Ownership, Risk and Efficiency.

JEL Classification: G21, G28, G32.

(C) The Authors, 2019. This article is published with open access at Sumy State University.

Cite as: Djalilov, Kh., Ngoc Lam, T. (2019). Ownership, Risk and Efficiency in the Banking Sector of the ASEAN Countries. Financial Markets, Institutions and Risks, 3(2), 5-16. http://doi.org/10.21272/fmir.3(2).516.2019.

\section{Introduction}

Assessing the factors impacting banking efficiency is an important question for both policymakers and researchers. Currently there are only a limited number of studies that are exploring the determinants of banking efficiency (Delis et al., 2017; Dong et al., 2017; Fiordelisi et al., 2011), also, the studies focusing on the banking efficiency in South East Asia are limited. Thus, the aim of this study is to investigate the effects of ownership and risk on the banking efficiency in the ASEAN (the Association of South East Asian Nations) countries for the period 2011-2016.

Banks play a leading role in the financial systems of emerging countries. They do this by (1) providing monetary payments at lower costs, (2) mobilising and allocating funds in the most efficient way, and (3) improving the saving and investment that are important for sustainable economic growth. Following the Asian financial crisis (1997), and the recent global financial crisis (2007-2009), the banking sectors of the ASEAN countries have undergone significant reforms and deregulation. Moreover, the ASEAN Central Bank Governors endorsed the ASEAN Banking Integration Framework (ABIF) in 2014. The aim of this framework is to improve the quality of financial services, promote competition, increase the access to other ASEAN markets, and strengthen the financial stability, as well as to facilitate the regulatory and supervisory cooperation among the ASEAN countries. Therefore, it is interesting to explore the determinants of the banking efficiency in these countries. 
This study contributes to the existing research in several aspects. Firstly, this study focuses on the ASEAN countries while considering the post crisis (2011-2016) period. Secondly, this paper uses more extended ownership categories, such as widely-held, banks, institutional, industrial, family as well as state/public. Finally, this research investigates the effects of low-risk, medium-risk and high-risk levels on banking efficiency.

The paper proceeds as follows. Section 2 briefly describes the economic and the institutional conditions of the ASEAN countries. Section 3 develops the hypotheses, and section 4 discusses the data and its sources. Section 5 analyses the results and the final section concludes them.

\section{Economic and Institutional environment in ASEAN}

The ASEAN was established on 8 August 1967 by the five original member countries (ASEAN-5), namely, Indonesia, Malaysia, Philippines, Singapore and Thailand. Then, Brunei Darussalam joined on 8 January 1984, Vietnam on 28 July 1995, Lao PDR and Myanmar on 23 July 1997, and Cambodia on 30 April 1999. The aim of the association is to accelerate and sustain the region's economic growth, social progress, and cultural development, as well as to promote regional peace and stability through justice.

The ASEAN as a region is among one of the fastest growing in the world. Particularly, the region's GDP has more than quadrupled, increasing from USD 577 billion in 1999 to USD 2,500 billion in 2016 making it the world's sixth-largest economy (The Future of ASEAN Time to Act, 2018). Moreover, the ASEAN has managed to sustain the average growth rate of $5 \%$ over the past 10 years, while the world's average growth for the same period has remained at $3 \%$.

In addition, the ASEAN as a region is among one of the most successful that is controlling price volatility. During the post-global crisis, the region initially experienced high inflation rates (Figure 1). However, the monetary authorities of the member countries have managed to control the inflation rates below $3 \%$ (since 2013) successfully implementing an inflation-targeting monetary policy.

\section{Inflation, GDP deflator (annual \%)}

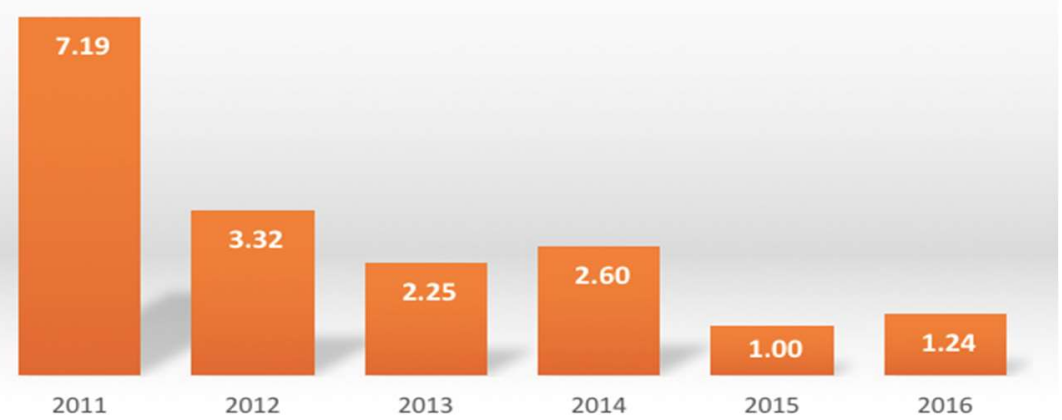

Figure 1. Inflation, GDP deflator (annual \%)

Source: World Bank Development Indicators, 2018.

On the other hand, the ASEAN countries are slow institutional reformers. The statistics in Table 1 below show the dynamics of six governance indicators from the World Governance Indicators of the World Bank, where each indicator ranges from -2.5 (lowest) to 2.5 (highest).

The first indicator, Voice and Accountability, shows whether citizens have a right to select their government. This indicator additionally comprises freedom of expression, freedom of association, and a free media. In addition, the second indicator Political Stability captures the possibility of the political destabilisation of a government caused by unconstitutional or violent events. The statistics for both indicators remain negative implying that the region remains under-developed in terms of its institutional development. However, the scores for both Government Effectiveness and Regulatory quality are relatively higher. This implies that the quality of policy formulation and its implementation are of good standards. They also show that the governments have been advocating the development of private sectors.

The following indicator Rule of Law indicates the quality of the law (i.e. contract enforcement, property rights, the police, and the courts). Although the ASEAN countries have made significant improvements, the scores still remain very low showing the presence of a lower quality of law. Finally, Control of Corruption refers to 
the extent to which public power is exercised for private gain. Similar to the previous indicators, the scores for Control of Corruption remain very low.

Table 1. Dynamics of Governance Indicators

\begin{tabular}{|c|c|c|c|c|c|c|}
\hline Years & $\begin{array}{c}\text { Voice and Account- } \\
\text { ability }\end{array}$ & $\begin{array}{c}\text { Political Stabil- } \\
\text { ity }\end{array}$ & $\begin{array}{c}\text { Government Ef- } \\
\text { fectiveness }\end{array}$ & $\begin{array}{c}\text { Regulatory } \\
\text { Quality }\end{array}$ & $\begin{array}{c}\text { Rule of Law } \\
\text { Control of Cor- } \\
\text { ruption }\end{array}$ \\
\hline 2011 & -0.412 & -0.306 & 0.497 & 0.233 & 0.049 & -0.027 \\
\hline 2012 & -0.333 & -0.228 & 0.479 & 0.295 & 0.066 & 0.044 \\
\hline 2013 & -0.343 & -0.206 & 0.499 & 0.321 & 0.095 & 0.102 \\
\hline 2014 & -0.399 & -0.101 & 0.620 & 0.435 & 0.200 & 0.100 \\
\hline 2015 & -0.425 & -0.137 & 0.579 & 0.427 & 0.177 & 0.083 \\
\hline 2016 & -0.496 & -0.135 & 0.573 & 0.413 & 0.279 & 0.078 \\
\hline
\end{tabular}

Source: World Governance Indicators of World Bank.

The ASEAN countries have been making significant progress in their financial system development, particularly in banking sector development. Figure 2 below presents Domestic credit to the private sector by banks. In advanced economies, the share of domestic credit given to the private sector relative to GDP reaches $100 \%$ or even higher. Figure 2 shows the comparison of domestic credit given to the private sector by the banks (as a percentage of GDP) in 6 ASEAN countries (Indonesia, Malaysia, the Philippines, Singapore, Thailand and Vietnam) implying that the countries have been steadily increasing it over the period 2011-2016.

\section{Domestic credit to private sector by banks (\% of GDP)}

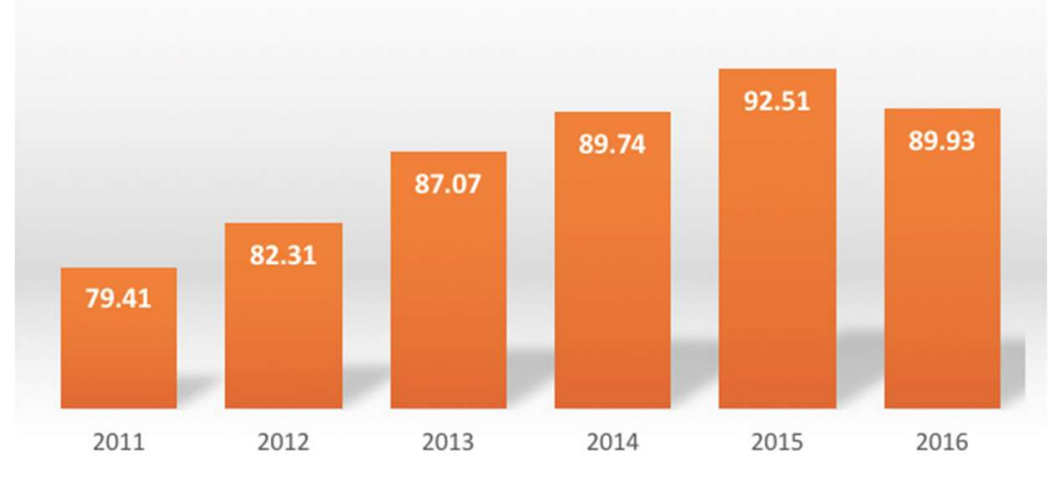

Figure 2. Domestic credit to the private sector by banks (\% of GDP)

Source: World Bank Development Indicators, 2018.

Thus, the discussions show that the ASEAN countries have specific features not observable in other countries. Particularly, they are fast-growing economies and they have financial sectors with underdeveloped institutions. Therefore, the research focusing on this area is interesting and delivers new evidence.

\section{Hypotheses development}

The bank's corporate governance, regulation and performance have received significant research interest particularly following the Asian (1997) as well as the recent global financial crisis (2007-2009). However, the majority of the relevant studies focus on the US, European and Chinese banking sectors. To fill in this gap this paper explores the effects of (1) the various categories of bank ownership, and (2) their risk-taking behaviour on bank efficiency.

Many studies focusing on the impact of ownership on bank efficiency consider three mutually exclusive categories of ownership, such as foreign, private and state (Fries and Taci, 2005; Hasan and Marton, 2003; Karas et al., 2010). Those investigating transition countries and emerging markets find foreign banks to be the most efficient relative to domestic privately-owned and state-owned banks (Fries and Taci, 2005; Hasan and Marton, 2003). In this study, however, we extend the relevant research by introducing two groups of bank ownership, such as banks with no controlling shareholder (dispersed ownership), as well as the banks with controlling shareholders (concentrated ownership), as described by Saghi-Zedek (2016).

The agency theory is the dominant theoretical reference analysing the relationship between owners and managers. According to the theory, small shareholders have relatively weak motivation to monitor the managers of banks with dispersed ownership (widely-held banks). This provides an opportunity for the managers to 
Financial Markets, Institutions and Risks, Volume 3, Issue 2, 2019

ISSN (online) - 2521-1242 ISSN (print) - 2521-1250

prioritise their private interests (employment risk aversion and empire building), which may ultimately lead to lower bank performances (Thomsen and Pedersen, 2000). For example, the managers are more likely to maintain value-reducing diversification (activities) in the firms with dispersed ownership.

However, empirical studies provide contradicting results on the ownership-performance link. Particularly, Haw et al. (2010) find that dispersed banks show better performance, higher cost efficiency, greater return volatility, and lower insolvency risk relative to the banks with higher control concentration. The reason might be that concentrated banks tend to become an easy tool for tunnelling, since controlling shareholders could lend credits with more favourable terms to connected partners. Similarly, family-controlled and corporatecontrolled banks in five East Asian countries experienced high loan growth over the pre-Asian financial crisis period (Laeven, 1999). Thus, as the theory and empirical studies deliver contradicting predictions on the ownership-performance link, our first hypothesis is as follows:

\section{Hypothesis 1. Widely-held banks exhibit lower efficiency.}

On the other hand, larger owners have stronger incentives to monitor the bank managers and are more powerful to increase their inclination to maximise the shareholder value. However, not all larger owners contribute to higher performance. Empirical studies state that larger bank, institutional and industrial owners are able to transfer their experience to improve bank performance (Saghi-Zedek, 2016). Particularly, institutional investors (financial companies) tend to have experience of managing riskier activities, while banks hold valuable information about their clients and customers. Moreover, industrial companies tend to manage sophisticated and diversified assets portfolios. Thus, institutional investors, banks and industrial companies can transfer their unique knowledge and expertise to their owned banks where the latter lack experience. This may ultimately lead banks to improve their performance.

\section{Hypothesis 2. Larger owners such as banks, institutional investors and industrial companies improve bank performance.}

However, Demsetz and Lehn (1985) find an insignificant link between concentrated ownership and profitability when they control for the effects of other variables. Similarly, Iannotta et al. (2007) find no relationship between ownership concentration and banks profitability.

Family owners are reluctant to give up control, and, thus, are risk-averse. In addition, they do not want to attract equity from the stock markets. Moreover, the expropriation hypothesis states that families derive private benefits from running the company at the expense of minority shareholders (Thomsen and Pedersen, 2000). Moreover, government ownership internalises the link between the company and the government. As governments pay special attention to political goals, their non-profit maximisation behaviour leads to lower performance in state-owned companies (Thomsen and Pedersen, 2000). Thus, our third hypothesis is as follows:

\section{Hypothesis 3. Banks with family and state ownership exhibit lower efficiency.}

Early studies put forward several hypotheses to explain the link between risk and efficiency. In particular, Berger and De Young (1997) introduce the "cost skimping" hypothesis. According to this hypothesis, banks appear to be more cost efficient when they use fewer resources for screening and monitoring loans. In the short-run, therefore, the amount of non-performing loans remains unchanged. However, in the medium- and long-run banks need to obtain more resources to administer future higher risk (due to higher levels of nonperforming loans). Therefore, banks obtain higher levels of profits in the short-run due to the cost of laxer loan screening and monitoring. Moreover, the impact of risk on efficiency might be non-linear implying that the effect becomes negative beyond a certain level of risk-taking. Thus, our hypothesis is as follows:

\section{Hypothesis 4. Risk improves banking efficiency}

\section{Data and methods}

3.1 Sample. The sample consists of 71 banks from six countries of the ASEAN, such as Indonesia, Malaysia, Philippines, Singapore, Thailand and Vietnam. The data are an unbalanced panel, sourced from Orbis. All commercial banks, whose financial statements are available for at least three years during the period 20112016, are included. Data for GDP growth, GDP per capita growth, real interest rate and interest rate spread are from the World Bank World Development Indicators. The control of corruption data are fromthe World Bank Governance Indicatorsand the legal origin data are from La Porta (1999). All financial and economic data are deflated by their corresponding CPIs to the 2011 price level to control for inflation effects and are 
converted to constant US dollars by using the 2005 PPP conversion rates following the relevant studies (Fu et al., 2014).

3.2. Measuring efficiency (dependent variable). To estimate a measure of efficiency we use stochastic frontier analysis (SFA), as proposed by Battese and Coelli (1995). This allows the measurement of inefficiency for each bank from the best-practice frontier in a single step estimation incorporating bank-, industry- and country-specific variables. We follow Gaganis and Pasiouras (2013) and Luo et al. (2016) in selecting input and output variables for the profit frontier and take an intermediation approach. That is, we treat banks as financial intermediaries collecting funds (deposits) as inputs, and transforming them into loans or other assets. Thus, we choose two output prices: (1) the ratio of interest income to loans (p1), and (2) the ratio of noninterest income to other earning assets (p2). There are three input prices: (1) the cost of loanable funds estimated by the ratio of interest expenses to total deposits (w1); (2) the cost of physical capital measured by the ratio of overhead expenses to fixed assets (w2); and (3) the cost of labour calculated by the ratio of personnel expenses to total assets (w3). To control for different bank risk profiles, we include Equity as a quasi-fixed input following Berger and Mester (1997). We also use w3 to normalise prices and include a time trend to account for the changes in technology over time ( $\mathrm{T}=0$ for $2010, \mathrm{~T}=1$ for 2011 , to $\mathrm{T}=6$ for 2016).

The profit function also includes GDP per capita growth and interest rate spread to account for cross-country heterogeneity. We consider a multi-product transcendental logarithmic (translog) function to estimate the profit efficiency of banks. This functional form is widely used in previous studies and provides more flexibility when modelling the efficiency frontier (Luo et al., 2016; Tabak et al., 2012). The model specification for the frontier is as follows:

$\ln \frac{\text { profit }}{\mathrm{w}_{3}}$

$=\beta_{0}+\beta_{1} \ln \frac{p_{1}}{w_{3}}+\beta_{2} \ln \frac{p_{2}}{w_{3}}+\beta_{3} \ln \frac{w_{1}}{w_{3}}+\beta_{4} \ln \frac{w_{2}}{w_{3}}+\beta_{5} \frac{1}{2} \ln \left(\frac{p_{1}}{w_{3}}\right)^{2}+\beta_{6} \ln \frac{p_{1}}{w_{3}} \ln \frac{p_{2}}{w_{3}}$

$+\beta_{7} \frac{1}{2} \ln \left(\frac{p_{2}}{w_{3}}\right)^{2}+\beta_{8} \frac{1}{2} \ln \left(\frac{w_{1}}{w_{3}}\right)^{2}+\beta_{9} \ln \frac{p_{1}}{w_{3}} \ln \frac{w_{1}}{w_{3}}+\beta_{10} \ln \frac{p_{2}}{w_{3}} \ln \frac{w_{1}}{w_{3}}+\beta_{11} \frac{1}{2} \ln \left(\frac{w_{2}}{w_{3}}\right)^{2}+\beta_{12} \ln \frac{p_{1}}{w_{3}} \ln \frac{w_{2}}{w_{3}}$

$+\beta_{13} \ln \frac{p_{2}}{w_{3}} \ln \frac{w_{2}}{w_{3}}+\beta_{14} \ln \frac{w_{1}}{w_{3}} \ln \frac{w_{2}}{w_{3}}+\beta_{15} \ln$ (equity) $+\beta_{16} \frac{1}{2} \ln$ (equity) $)^{2}$

$+\beta_{17} \ln$ (equity) $\ln \frac{p_{1}}{w_{3}}+\beta_{18} \ln$ (equity) $\ln \frac{p_{2}}{w_{3}}+\beta_{19} \ln$ (equity) $\ln \frac{w_{1}}{w_{3}}+\beta_{20} \ln$ (equity) $\ln \frac{w_{2}}{w_{3}}$

$+\beta_{21} \mathrm{~T}+\beta_{22} T^{2}+\beta_{23} \mathrm{~T} \ln \frac{p_{1}}{w_{3}}+\beta_{24} \mathrm{~T} \ln \frac{p_{2}}{w_{3}}+\beta_{25} \mathrm{~T} \ln \frac{w_{1}}{w_{3}}+\beta_{26} \mathrm{~T} \ln \frac{w_{2}}{w_{3}}+\beta_{27} \mathrm{~T} \ln$ (equity)

$+\beta_{28}$ GDPpercapitagrowth $+\beta_{29}$ Interestratespread ${ }_{\mathrm{j}}+\beta_{30} \mathrm{NPI}-u_{i, t}+v_{i, t}$

where $v_{\mathrm{i}, \mathrm{t}}$ is the random error assumed to be independent and identically distributed $\mathrm{N}\left(0, \sigma_{v}^{2}\right)$; $\mathrm{u}_{\mathrm{i}, \mathrm{t}}$ is a nonnegative random inefficiency term assumed to be independent but not identically distributed. The term $\mathrm{u}_{\mathrm{i}, \mathrm{t}}$ follows a truncated-normal distribution with truncation (at zero) of the $\mathrm{N}\left(\mathrm{m}_{\mathrm{i}, t}, \sigma_{u}^{2}\right)$. The mean is defined as $\mathrm{m}_{\mathrm{i}, \mathrm{t}}=\mathrm{z}_{\mathrm{i}, t} \delta$, where $\mathrm{z}_{\mathrm{i}, \mathrm{t}}$ is a $(1 \mathrm{x} \mathrm{M})$ vector of explanatory variables associated with the technical inefficiency effectsin (1), while $\delta$ is a (M x 1) vector of unknown parameters to be estimated in (1). Profit is the pre-tax profits of bank $i$ at time $t$. The coefficients of (1) are estimated in a single-step by using the maximum likelihood approach. ${ }^{1}$

Following Bos and Koetter (2011), we incorporate an additional independent variable, the negative profit indicator (NPI), to account for those banks that report negative profits, as the dependent variable requires the natural logarithmic transformation, and this is undefined for negative values. In particular, profit is assigned a value of 1 when profit $\leq 0$; then, NPI equals 1 when profit $\geq 0$ and equals the absolute value of profit when the latter is negative. Tabak et al. (2011), Gananis and Pasiouras (2013) and Luo et al. (2016) use this approach when modeling banks with negative profit.

3.3. Ownership and risk variables. We follow Saghi-Zedek (2016) to form ownership variables. Particularly, we fix a minimum percentage of shares above which the owners exert effective controls over banks. This paper uses a control threshold of 10\% following Saghi-Zedek (2016). The ownership relevant data are from Orbis and the banks' annual reports disclosed in their websites. We consider banks as widely-held (Widely-

\footnotetext{
${ }^{1}$ Once the point estimates of $\mathrm{u}_{\mathrm{i}, \mathrm{t}}$ (inefficiency) are obtained, estimates of technical efficiency are defined as Efficiency=exp(-u).
} 
held ownership) when those banks have no controlling shareholder. As controlling shareholders we classify five categories, such as banks (Bank ownership), institutions including insurance companies, mutual and pension funds (Institutional ownership), industrial companies (Industry ownership), managers, individuals and family investors (Family ownership) as well as state/public authorities (State ownership) following SaghiZedek (2016). We do not look at the effects of the largest shareholder, but rather assess the controlling effects of all shareholders holding at least $10 \%$ of bank shares. Therefore the dummy variables with controlling shareholders are not mutually exclusive implying that one bank may have all five controlling shareholders in this study, which is consistent with Saghi-Zedek (2016).

We use the $\mathrm{Z}$ score as a risk variable, which has long been established in the literature (Agoraki et al., 2011). It is monotonically associated with the probability of bank failure and is expressed as follows:

$Z_{i, t}=\frac{\mathrm{ROAi,t}+\left(\frac{\mathrm{E}}{\mathrm{A}}\right)_{i, t}}{\mathrm{SD}(\mathrm{ROA}) \mathrm{i}, \mathrm{t}}$

where ROA is return on assets, $\mathrm{E} / \mathrm{A}$ is the equity to asset ratio (or Capital ratio) and $\mathrm{SD}(\mathrm{ROA})$ is the standard deviation of ROA. Since the $\mathrm{Z}$ score indicates the distance to insolvency, a higher $\mathrm{Z}$ score implies a bank is less risky. As the $\mathrm{Z}$ score is highly skewed we use the natural logarithm, following Beck et al. (2013).

3.4. Other control variables. To account for bank and cross-country heterogeneity, we use a number of variables common in the literature (Agoraki et al., 2011; Delis and Kouretas, 2011; Tabak et al., 2012). Particularly, we use size, capital ratio, liquidity, traditional banking and diversification as bank-specific variables. Since economic conditions impact on bank behaviour, we use GDP growth, GDP per capita growth and real interest rate to account for the economic environment. As institutional variables we utilise the data on the control of corruption and the legal origin. The control of corruption shows the perceptions of the extent to which public power is exercised for private gain and is from the World Bank Governance Indicators of the World Bank. The data for Legal origin indicate the commercial code of each country and are taken from La Porta et al. (1999). The legal origins of the countries in this sample reflect the UK legal origin (Malaysia, Singapore and Thailand) and French legal origin (Indonesia, Philippines and Vietnam).

Table 2. Description and Source of Data

\begin{tabular}{|c|c|c|}
\hline Variables & Description & Sources \\
\hline \multicolumn{3}{|l|}{ 1.Main variables } \\
\hline $\ln Z_{\mathrm{ROA}}$ score & Natural logarithm of Z score & Orbis \\
\hline Widely-held ownership & Dummy equal to one when there is no controlling shareholder, and zero otherwise. & \multirow{6}{*}{$\begin{array}{l}\text { Orbis and annual re- } \\
\text { ports via banks' web- } \\
\text { sites }\end{array}$} \\
\hline Bank ownership & $\begin{array}{l}\text { Dummy equal to one if the bank has at least another banking institution as a control- } \\
\text { ling shareholder, and zero otherwise. }\end{array}$ & \\
\hline Institutional ownership & $\begin{array}{l}\text { Dummy equal to one if the bank has at least an institutional investor as a controlling } \\
\text { shareholder, and zero otherwise. }\end{array}$ & \\
\hline Industry ownership & $\begin{array}{l}\text { Dummy equal to one if the bank has at least an industrial investor as a controlling } \\
\text { shareholder, and zero otherwise. }\end{array}$ & \\
\hline State ownership & $\begin{array}{l}\text { Dummy equal to one if the bank has at least a state as a controlling shareholder, and } \\
\text { zero otherwise. }\end{array}$ & \\
\hline Family ownership & $\begin{array}{l}\text { Dummy equal to one if the bank has at least a family investor as a controlling share- } \\
\text { holder, and zero otherwise. }\end{array}$ & \\
\hline \multicolumn{3}{|l|}{ 2. Control variables } \\
\hline \multicolumn{3}{|c|}{ 2A. Bank-specific control variables } \\
\hline Size & Natural logarithm of total assets & \multirow{6}{*}{ Orbis } \\
\hline Capital Ratio & Equity/Total Assets & \\
\hline Diversification & Non-interest income/Pre-tax profit & \\
\hline Liquidity (1) & Gross loans / Total deposit & \\
\hline Liquidity (2) & Liquid assets / Total deposit & \\
\hline Traditional banking & Gross loans / total assets & \\
\hline \multicolumn{3}{|c|}{ 2B. Macroeconomic control variables } \\
\hline GDP growth & Annual percentage changes in GDP & \multirow{4}{*}{$\begin{array}{l}\text { World Bank's World } \\
\text { Development Indica- } \\
\text { tors }\end{array}$} \\
\hline GDP per capita growth & Annual percentage changes in GDP per capita & \\
\hline Real interest rate & It is approximately the nominal interest rate minus the inflation rate. & \\
\hline Interest rate spread & It is the difference between borrowing and lending rates. & \\
\hline \multicolumn{3}{|c|}{ 2C. Institutional control variables } \\
\hline Control of corruption & $\begin{array}{l}\text { It shows the perceptions of the extent to which public power is exercised for private } \\
\text { gain. }\end{array}$ & $\begin{array}{l}\text { World Bank Govern- } \\
\text { ance Indicators. }\end{array}$ \\
\hline $\begin{array}{l}\text { Legal origin (UK) } \\
\text { Legal origin (French) }\end{array}$ & This indicates the commercial code of each country (UK or French). & La Porta et al. (1999). \\
\hline
\end{tabular}

3.5. Summary statistics. Descriptive statistics and correlations for the banks-specific variables are in Table 
Financial Markets, Institutions and Risks, Volume 3, Issue 2, 2019 ISSN (online) - 2521-1242 ISSN (print) - 2521-1250

2. The standard deviation of Size, Diversification and $Z_{R O A}$ score indicates that these variables significantly vary across the countries. Also, Table 3 (see in Appendix) shows that the efficiency is negatively correlated with Bank ownership, Industry ownership and Family ownership. However, this association is positive with Institutional ownership and State ownership. This implies that the banks with Bank, Industry and Family ownership are possibly less efficient, but the opposite might be true for the banks with Institutional and State ownership. All correlations are less than $45 \%$ excluding the correlation between Liquidity (1) and Traditional banking; however, the latter was removed from the regressions as it was statistically not significant.

Finally, Table-3 presents the means of the country-environmental variables (for the period 2011-2016) and these areused in the specifications. Particularly, the table includes the macroeconomic and the institutional variables. The average means of GDP growth and GDP per capita growth are higher in Malaysia and Singapore implying that these countries experienced relatively higher macroeconomic growth. In addition, all countries have positive real interest rates; however, the rates are again higher in Malaysia and Singapore.

Table 4. Country-environmental variables

\begin{tabular}{|l|c|c|c|c|c|c|}
\hline & GDP growth & $\begin{array}{l}\text { GDP per capita } \\
\text { growth }\end{array}$ & $\begin{array}{l}\text { Real interest } \\
\text { rate }\end{array}$ & $\begin{array}{l}\text { Control of cor- } \\
\text { ruption }\end{array}$ & $\begin{array}{l}\text { Legal origin } \\
\text { (UK) }\end{array}$ & $\begin{array}{l}\text { Legal } \\
\text { (French) }\end{array}$ \\
\hline Indonesia & 0.001 & 0.001 & 0.002 & -0.547 & 0 & 1 \\
\hline Malaysia & 2.777 & 1.802 & 1.565 & 0.231 & 1 & 0 \\
\hline Philippines & 0.259 & 0.186 & 0.157 & -0.505 & 0 & 1 \\
\hline Singapore & 3.205 & 1.765 & 4.452 & 2.088 & 1 & 0 \\
\hline Thailand & 0.180 & 0.155 & 0.291 & -0.397 & 1 & 0 \\
\hline Vietnam & 0.001 & 0.001 & 0.001 & -0.47 & 0 & 1 \\
\hline
\end{tabular}

Source: GDP growth, GDP per capita growth and Real interest rate are from World Bank Development Indicators, Control of corruption is from World Bank Governance Indicators and Legal origin is from La Porta et al. (1999).

World Governance Indicators run from approximately -2.5 to 2.5 and higher values correspond to better governance. This implies that Malaysia and Singapore have a relatively better governance of corruption in place.

\section{Estimation and Results}

4.1. Model specification. In this study, we investigate the effects of ownership and risk on the bank efficiency in the ASEAN countries by using system GMM (Arellano and Bover, 1995; Blundell and Bond, 1998) with Windmeijer-corrected standard errors. The advantage of the system GMM is that the approach successfully addresses problems ofendogeneity. Bank strategies are not exogenous and are highly dependent on bank performances. Therefore, we treat bank-specific variables, such as Size, Capital Ratio, Liquidity (1), Liquidity (2), Traditional banking and Diversification, as endogenous variables (Saghi-Zedek, 2016). However, bank ownership and risk remain stable in the ASEAN countries over the post-crisis period2011-2016, and, therefore, we consider these variables as exogenous. In addition, we treat institutional and macro variables as exogenous. Our specification for the endogenous and exogenous variables is consistent with the literature (Dong et al., 2017; Saghi-Zedek, 2016).

System GMM assumes that the only available instruments are the lags of instrumented variables (Roodman, 2009). We limit the number of instruments restricting the lag range to three, and test the overall validity of the instruments using the Hansen-test. We also perform the Arellano and Bond test for the absence of the second order residual autocorrelation (AB test for AR (2)). The estimating equation is specified as follows:

$$
\begin{aligned}
\text { Efficiency }_{\mathrm{i}, \mathrm{j}, \mathrm{t}}= & \text { SEfficiency }_{\mathrm{i}, \mathrm{j}, \mathrm{t}-1}+\mathrm{b}_{1} \text { Bank }_{\mathrm{i}, \mathrm{j}, \mathrm{t}}+\mathrm{b}_{2} \text { Macro }_{\mathrm{j}, \mathrm{t}}+\mathrm{b}_{3} \text { Institutions }_{\mathrm{j}, \mathrm{t}}+\mathrm{b}_{4} \text { Ownership }_{\mathrm{ijt}} \\
& +\mu_{\mathrm{i}, \mathrm{j}, \mathrm{t}}
\end{aligned}
$$

for bank $i$, in country $j$ at time $t$. The coefficient $\delta$ lies between 0 and 1 and indicates the speed of adjustment. Bank includes bank-specific variables such as Size, Capital ratio, Liquidity (1), Liquidity (2), Traditional banking, Diversification and the natural logarithm of $Z$ score ( $\ln Z_{\mathrm{ROA}}$ score), while Macro comprises GDP growth, GDP per capita growth and Real interest rate. In addition, Institutions includes Controlofcorruption and Legal origin variables. Finally, ownership represents widely-held banks and five ownership controlling dummies.

We apply the "general-to-specific" method when deciding which control variables should be included in the model following Klomp and De Haan (2012). Initially, we estimate model 1 (Table 4) including all control variables and year dummies from 2012 to 2016 without our main variables. Then, we delete the least significant variable and re-estimate the model. We repeat this procedure until the model (1) includes only significant 
Financial Markets, Institutions and Risks, Volume 3, Issue 2, 2019

ISSN (online) - 2521-1242 ISSN (print) - 2521-1250

variables at a $10 \%$ level. The main variables of interest, such as the ownership and risk, are then added individually in models $2-8$, and model 9 includes all variables.

4.2. Econometric results and discussions. Table 5 shows that the coefficients are quite stable across models, and the Hansen test indicates no evidence of over-identifying restrictions. Although Table 5 shows the presence of first-order autocorrelation, this does not imply that the estimates are inconsistent, as this would only be the case if second-order autocorrelation was present (Arellano and Bond, 1991). The Arellano-Bond (AB) test results in Table 5 indicate the absence of second-order autocorrelation.

Moreover, the results for the control variables indicate that the capital ratio is negatively associated with profit efficiency implying that highly capitalized banks are less profit efficient. More liquid banks, however, appear to be more profit efficient. The results for the diversification, however, are not stable across the models.

Table 5. Results (1)

\begin{tabular}{|c|c|c|c|c|c|c|c|c|c|}
\hline Variables & (1) & (2) & (3) & (4) & (5) & (6) & (7) & (8) & (9) \\
\hline \multirow[t]{2}{*}{ Capital ratio } & $-5.147 * * *$ & $-6.518 * * *$ & $-5.129 * * *$ & $\begin{array}{l}- \\
6.117 * * \\
*\end{array}$ & $-5.158 * * *$ & $-5.040 * * *$ & $-5.106 * * *$ & $-6.141 * * *$ & $-7.348 * * *$ \\
\hline & $(1.759)$ & $(1.558)$ & (1.757) & $(1.516)$ & $(1.791)$ & $(1.760)$ & $(1.734)$ & (1.898) & $(1.662)$ \\
\hline \multirow[t]{2}{*}{ Liquidity (1) } & $0.715^{*}$ & 0.528 & $0.854^{*}$ & $0.598^{*}$ & $0.701^{*}$ & $0.687^{*}$ & $0.706^{*}$ & 0.597 & 0.514 \\
\hline & $(0.377)$ & $(0.352)$ & $(0.428)$ & $(0.339)$ & $(0.364)$ & $(0.371)$ & $(0.379)$ & $(0.387)$ & $(0.365)$ \\
\hline \multirow[t]{2}{*}{ Liquidity (2) } & $1.288 * * *$ & $1.114 * * *$ & $1.389 * * *$ & $\begin{array}{l}1.199 * * \\
*\end{array}$ & $1.281 * * *$ & $1.270 * * *$ & $1.288 * * *$ & $1.249 * * *$ & $1.175 * * *$ \\
\hline & $(0.251)$ & $(0.231)$ & $(0.283)$ & $(0.248)$ & $(0.246)$ & $(0.253)$ & $(0.249)$ & $(0.247)$ & $(0.241)$ \\
\hline \multirow[t]{2}{*}{ Diversification } & $-0.039 *$ & $-0.046^{*}$ & -0.028 & -0.038 & $-0.039 *$ & $-0.038 *$ & $-0.038^{*}$ & -0.024 & -0.019 \\
\hline & $(0.022)$ & $(0.023)$ & $(0.018)$ & $(0.024)$ & $(0.022)$ & $(0.022)$ & $(0.022)$ & $(0.028)$ & $(0.025)$ \\
\hline \multirow[t]{2}{*}{ Widely-held ownership } & & $-0.252 * * *$ & & & & & & & $-0.206^{*}$ \\
\hline & & $(0.083)$ & & & & & & & $(0.118)$ \\
\hline \multirow[t]{2}{*}{ Bank ownership } & & & $-0.169 * *$ & & & & & & $-0.140^{*}$ \\
\hline & & & $(0.081)$ & & & & & & $(0.083)$ \\
\hline \multirow[t]{2}{*}{ Institutional ownership } & & & & 0.105 & & & & & 0.010 \\
\hline & & & & $(0.065)$ & & & & & $(0.078)$ \\
\hline \multirow[t]{2}{*}{ Industry ownership } & & & & & 0.006 & & & & 0.019 \\
\hline & & & & & $(0.067)$ & & & & $(0.080)$ \\
\hline \multirow[t]{2}{*}{ State ownership } & & & & & & 0.053 & & & 0.038 \\
\hline & & & & & & $(0.067)$ & & & $(0.068)$ \\
\hline \multirow[t]{2}{*}{ Family ownership } & & & & & & & 0.001 & & 0.021 \\
\hline & & & & & & & $(0.067)$ & & $(0.068)$ \\
\hline \multirow[t]{2}{*}{$\ln Z_{\mathrm{ROA}}$ score } & & & & & & & & $0.109^{*}$ & $0.103 * *$ \\
\hline & & & & & & & & $(0.061)$ & $(0.051)$ \\
\hline Number of instruments & 26 & 27 & 27 & 27 & 27 & 27 & 27 & 27 & 33 \\
\hline Hansen t-test & 0.417 & 0.657 & 0.500 & 0.484 & 0.419 & 0.431 & 0.412 & 0.479 & 0.715 \\
\hline AB test AR (1) (p-value) & 0.030 & 0.048 & 0.021 & 0.033 & 0.031 & 0.032 & 0.029 & 0.027 & 0.024 \\
\hline AB test AR (2) (p-value) & 0.818 & 0.763 & 0.962 & 0.841 & 0.818 & 0.813 & 0.818 & 0.973 & 0.949 \\
\hline Observations & 305 & 305 & 305 & 305 & 305 & 305 & 305 & 305 & 305 \\
\hline
\end{tabular}

Constant term included but not reported. *** $\mathrm{p}<0.01, * * \mathrm{p}<0.05$, $* \mathrm{p}<0.1$; Year dummies 2012-2016 are included. Windmeijer-corrected standard errors are in parentheses.

The results for the ownership effects (Table 4) indicate that the widely-held banks and the banks with the bank controlling ownership display lower efficiency. Moreover, overall risk taking also appears to have positive efficiency effects. Particularly, for a bank with the median level of risk, a one standard deviation increases in the proportion of risk (57.368 units) leads to an increase in a profit efficiency of 6.25 units.

To check the robustness of the results, we replace the risk variable with three risk dummy variables, such as Low risk banks ( $\geq$ Risk $\left.k_{\text {Mean }}+\sigma_{\text {Risk }}\right)$, Medium risk banks $\left(<\right.$ Ris $k_{\text {Mean }}+\sigma_{\text {Risk }}$ and $>$ Risk $\left.k_{\text {mean }}-\sigma_{\text {Risk }}\right)$ and High risk banks $\left(\leq\right.$ Risk $k_{\text {Mean }}-\sigma_{\text {Risk }}$ ) considering the fact that higher $\mathrm{Z}$ values (proxy for Risk) imply lower risk. The results for the alternative specification are presented in Table 6. 
Table 6. Results (2)

\begin{tabular}{|c|c|c|c|}
\hline Variables & (1) & (2) & (3) \\
\hline \multirow[t]{2}{*}{ Capital ratio } & $-7.566 * * *$ & $-7.114 * * *$ & $-6.873 * * *$ \\
\hline & $(1.546)$ & $(1.602)$ & $(1.413)$ \\
\hline \multirow[t]{2}{*}{ Liquidity (1) } & 0.508 & 0.516 & 0.466 \\
\hline & $\begin{array}{l}(0.399) \\
\end{array}$ & $(0.333)$ & $(0.318)$ \\
\hline \multirow[t]{2}{*}{ Liquidity (2) } & $1.045 * * *$ & $1.137^{* * * *}$ & $1.095 * * *$ \\
\hline & $(0.268)$ & $(0.249)$ & $(0.243)$ \\
\hline \multirow[t]{2}{*}{ Diversification } & -0.033 & -0.031 & -0.035 \\
\hline & $\begin{array}{ll}(0.025) \\
(025)\end{array}$ & $\begin{array}{ll}(0.024) \\
(0.024)\end{array}$ & $(0.022)$ \\
\hline \multirow[t]{2}{*}{ Widely-held ownership } & $-0.299 * *$ & $-0.261 * *$ & $-0.275^{* *}$ \\
\hline & $(0.113)$ & $(0.128)$ & $(0.123)$ \\
\hline \multirow[t]{2}{*}{ Bank ownership } & -0.119 & $-0.141^{*}$ & $-0.121^{*}$ \\
\hline & $\begin{array}{ll}(0.082) \\
(0.02\end{array}$ & $\begin{array}{ll}(0.077) \\
\end{array}$ & $(0.072)$ \\
\hline \multirow[t]{2}{*}{ Institutional ownership } & 0.055 & 0.096 & 0.071 \\
\hline & $(0.074)$ & $(0.087)$ & $(0.069)$ \\
\hline \multirow[t]{2}{*}{ Industry ownership } & 0.015 & 0.009 & 0.028 \\
\hline & $\begin{array}{ll}(0.076) \\
\end{array}$ & $\begin{array}{ll}(0.080) \\
\end{array}$ & $(0.074)$ \\
\hline \multirow[t]{2}{*}{ State ownership } & 0.036 & 0.072 & 0.055 \\
\hline & $(0.066)$ & $(0.068)$ & $(0.062)$ \\
\hline \multirow[t]{2}{*}{ Family ownership } & 0.031 & 0.036 & 0.026 \\
\hline & $(0.061)$ & $(0.062)$ & $(0.056)$ \\
\hline \multirow[t]{2}{*}{ Low risk banks } & 0.353 & & \\
\hline & $(0.252)$ & & \\
\hline \multirow[t]{2}{*}{ Medium risk banks } & & -0.026 & \\
\hline & & $(0.088)$ & \\
\hline \multirow[t]{2}{*}{ High risk banks } & & & $-0.500^{* * *}$ \\
\hline & & & $(0.062)$ \\
\hline Number of instruments & 33 & 33 & 33 \\
\hline \begin{tabular}{|l|} 
Hansen t-test \\
\end{tabular} & 0.772 & 0.728 & 0.797 \\
\hline AB test $\mathrm{AR}(1)$ (p-value) & 0.039 & 0.034 & 0.021 \\
\hline $\mathrm{AB}$ test $\mathrm{AR}(2)$ (p-value) & 0.898 & 0.966 & 0.880 \\
\hline \begin{tabular}{|l} 
Observations \\
\end{tabular} & 305 & 305 & 305 \\
\hline
\end{tabular}

Constant term included but not reported. ${ }^{* *} \mathrm{p}<0.01,{ }^{* *} \mathrm{p}<0.05, * \mathrm{p}<0.1$. Year dummies 2012-2016 are included. Windmeijer-corrected standard errors are in parentheses.

The results presented in Table 5 are similar to those presented in Table 4. Particularly, Table 5 indicates that the coefficients are again quite stable across models, and the Hansen test indicates no evidence of over-identifying restrictions. In addition, Table 5 shows the absence of second-order autocorrelation. Moreover, the widely-held banks and the banks with bank controlling ownership appear to be less efficient. The banks taking high risks appear to be less efficient too. This is consistent with the "cost skimping" hypothesis implying that current higher risks may lower efficiency in the medium- and long-run (Berger and DeYoung, 1997).

\section{Conclusion}

The objective of this paper is to investigate the effects of certain categories of ownership and risk-taking activities on efficiency in the banking sector of the ASEAN countries. Therefore, we collected the data for 71 commercial banks from six countries of the ASEAN members, such as Indonesia, Malaysia, Philippines, Singapore, Thailand and Vietnam, for the period 2011-2016.

This study contributes to the literature in several aspects. Firstly, the research focusing on the banking efficiency in the ASEAN countries is limited. Secondly, this paper used more extended ownership categories, such as widely-held, banks, institutional, industrial, family, as well as state/public. Thirdly, this study investigated the effects of low-risk, medium-risk and high risk on banking efficiency.

Overall, the results show that the widely-held banks and the banks with the bank controlling ownership display lower efficiency inconsistent with Haw et al. (2010). Thus, the results imply that the widely-held ownership and the bank controlling ownership do not induce the managers to maximise bank efficiency in the ASEAN countries. According to the agency theory, managers have more opportunities to prioritise their private interests in widely-held banks, as small shareholders have relatively lower motivation to monitor managers' behaviour. Surprisingly, the results additionally show that banks (as owners) do not seem to be transferring their skills and experience to the banks they own, which would allow the latter to improve efficiency. 
Financial Markets, Institutions and Risks, Volume 3, Issue 2, 2019

ISSN (online) - 2521-1242 ISSN (print) - 2521-1250

On the other hand, the results indicate that the risk improves the efficiency in the banking sector of the ASEAN countries. However, the effect becomes negative as the level of risk-taking passes beyond a certain level and thus high-risk taking lowers efficiency. This is consistent with the "cost skimping" hypothesis (Berger and DeYoung, 1997).

From the policy perspectives, the results imply that the policymakers in the ASEAN countries should consider the ownership and risk effects while developing strategies to improve banking stability. Particularly, they need to discourage banks from taking high risks and limit widely-held and bank ownership in the banking sectors of the ASEAN countries.

\section{References}

1. Agoraki, M.-E.K., Delis, M.D., Pasiouras, F. (2011). Regulations, competition and bank risk-taking in transition countries. Journal of Financial Stability, 7(1), 38-48.

2. Arellano, M., Bond, S. (1991). Some tests of specification for panel data: Monte Carlo evidence and an application to employment equations. The Review of Economic Studies, 58(2), 277-297.

3. Arellano, M., Bover, O. (1995). Another look at the instrumental variable estimation of error-components models. Journal of Econometrics, 68(1), 29-51.

4. Battese, G.E., Coelli, T.J. (1995). A model for technical inefficiency effects in a stochastic frontier production function for panel data. Empirical Economics, 20(8), 325-332.

5. Beck, T., De Jonghe, O., Schepens, G. (2013). Bank competition and stability: cross-country heterogeneity. Journal of financial Intermediation, 22(2), 218-244.

6. Berger, A.N., DeYoung, R. (1997). Problem loans and cost efficiency in commercial banks. Journal of Banking and Finance, 21(6), 849-870.

7. Berger, A.N., Mester, L.J. (1997). Inside the black box: What explains differences in the efficiencies of financial institutions? Journal of Banking and Finance, 21(7), 895-947.

8. Blundell, R., Bond, S. (1998). Initial conditions and moment restrictions in dynamic panel data models. Journal of Econometrics, 87(1), 115-143.

9. Bos, J.W., Koetter, M. (2011). Handling losses in translog profit models. Applied Economics, 43(3), 307312.

10. Delis, M., Iosifidi, M., Tsionas, M.G. (2017). Endogenous bank risk and efficiency. European Journal of Operational Research, 260(1), 376-387.

11. Delis, M.D., Kouretas, G.P., 2011. Interest rates and bank risk-taking. Journal of Banking and Finance, 35(4), 840-855.

12. Demsetz, H., Lehn, K. (1985). The structure of corporate ownership: Causes and consequences. Journal of political economy, 93(6), 1155-1177.

13. Dong, Y., Girardone, C., Kuo, J.-M., 2017. Governance, efficiency and risk taking in Chinese banking. The British Accounting Review, 49(2), 211-229.

14. Fiordelisi, F., Marques-Ibanez, D., Molyneux, P. (2011). Efficiency and risk in European banking. Journal of Banking and Finance, 35(5), 1315-1326.

15. Fries, S., Taci, A. (2005). Cost efficiency of banks in transition: Evidence from 289 banks in 15 postcommunist countries. Journal of Banking and Finance, 29(1), 55-81.

16. Fu, X.M., Lin, Y.R., Molyneux, P. (2014). Bank competition and financial stability in Asia Pacific. Journal of Banking and Finance, 38, 64-77.

17. Gaganis, C., Pasiouras, F. (2013). Financial supervision regimes and bank efficiency: International evidence. Journal of Banking and Finance, 37(12), 5463-5475.

18. Hasan, I., Marton, K. (2003). Development and efficiency of the banking sector in a transitional economy: Hungarian experience. Journal of Banking and Finance, 27(12), 2249-2271.

19. Haw, I.-M., Ho, S.S., Hu, B., Wu, D. (2010). Concentrated control, institutions, and banking sector: An international study. Journal of Banking and Finance, 34(3), 485-497.

20. Iannotta, G., Nocera, G., Sironi, A. (2007). Ownership structure, risk and performance in the European banking industry. Journal of Banking and Finance, 31(7), 2127-2149.

21. Karas, A., Schoors, K., Weill, L. (2010). Are private banks more efficient than public banks? Evidence from Russia. Economics of Transition, 18(1), 209-244.

22. Klomp, J., De Haan, J. (2012). Banking risk and regulation: Does one size fit all? Journal of Banking and Finance, 36(12), 3197-3212.

23. La Porta, R., Lopez-de-Silanes, F., Shleifer, A., Vishny, R. (1999). The quality of government. The Journal of Law, Economics, and Organization 15(1), 222-279. 
24. Laeven, L., 1999. Risk and efficiency in East Asian banks. The World Bank.

25. Luo, Y., Tanna, S., De Vita, G. (2016). Financial openness, risk and bank efficiency: Cross-country evidence. Journal of Financial Stability, 24, 132-148.

26. Roodman, D. (2009). How to do xtabond2: An Introduction to Difference and System GMM in Stata. Stata Journal, 9(1), 86-136.

27. Saghi-Zedek, N. (2016). Product diversification and bank performance: does ownership structure matter? Journal of Banking and Finance, 71, 154-167.

28. Tabak, B.M., Fazio, D.M., Cajueiro, D.O. (2012). The relationship between banking market competition and risk-taking: Do size and capitalization matter? Journal of Banking and Finance 36(12), 3366-3381.

29. Tabak, B.M., Fazio, D.M., Cajueiro, D.O. (2011). Profit, cost and scale efficiency for Latin American banks: concentration-performance relationship.

30. The Future of ASEAN Time to Act. (2018). PwC.

31. Thomsen, S., Pedersen, T. (2000). Ownership structure and economic performance in the largest European companies. Strategic Management Journal, 21(6), 689-705. 


\section{Appendix}

Table 3. Summary statistics and correlation

\begin{tabular}{|c|c|c|c|c|c|c|c|c|c|c|c|c|c|c|c|c|}
\hline & & Mean & S.D. & (1) & (2) & (3) & (4) & $(5)$ & (6) & (7) & $(8)$ & (9) & $(10)$ & $(11)$ & (12) & (13) \\
\hline$(1)$ & Efficiency & 0.566 & 0.243 & & & & & & & & & & & & & \\
\hline$(2)$ & Size & 16.780 & 1.751 & 0.356 & & & & & & & & & & & & \\
\hline (3) & Capital ratio & 0.110 & 0.037 & -0.164 & -0.411 & & & & & & & & & & & \\
\hline (4) & Liquidity (1) & 0.801 & 0.178 & -0.062 & 0.136 & 0.247 & & & & & & & & & & \\
\hline (5) & Liquidity (2) & 0.172 & 0.090 & 0.092 & 0.066 & -0.002 & -0.305 & & & & & & & & & \\
\hline (6) & Traditional banking & 0.627 & 0.108 & -0.115 & 0.010 & 0.119 & 0.826 & -0.435 & & & & & & & & \\
\hline (7) & Diversification & 0.607 & 2.657 & -0.217 & 0.016 & 0.045 & 0.095 & -0.108 & 0.062 & & & & & & & \\
\hline$(8)$ & Widely held ownership & 0.046 & 0.210 & -0.088 & 0.065 & -0.216 & -0.101 & 0.044 & -0.060 & 0.066 & & & & & & \\
\hline (9) & Bank ownership & 0.476 & 0.500 & -0.135 & 0.003 & 0.037 & 0.293 & 0.084 & 0.261 & -0.035 & -0.063 & & & & & \\
\hline$(10$ & Institutional ownership & 0.586 & 0.493 & 0.140 & 0.019 & 0.075 & 0.068 & -0.113 & 0.051 & 0.113 & -0.113 & -0.051 & & & & \\
\hline (11) & Industry ownership & 0.701 & 0.459 & -0.066 & -0.208 & 0.082 & -0.013 & -0.061 & -0.084 & 0.093 & -0.016 & 0.063 & 0.357 & & & \\
\hline (12) & State ownership & 0.210 & 0.408 & 0.240 & 0.349 & -0.109 & 0.137 & 0.111 & 0.155 & -0.038 & -0.113 & -0.038 & -0.230 & -0.322 & & \\
\hline (13) & Family ownership & 0.504 & 0.501 & -0.066 & -0.362 & 0.214 & -0.023 & 0.024 & -0.072 & 0.076 & 0.072 & -0.038 & -0.045 & 0.022 & -0.142 & \\
\hline (14) & $\mathrm{Z}_{\mathrm{ROA}}$ score & 49.739 & 57.368 & 0.076 & -0.083 & 0.319 & 0.044 & 0.115 & 0.074 & 0.023 & -0.128 & 0.067 & 0.186 & 0.093 & -0.063 & 0.194 \\
\hline
\end{tabular}

